Arab Univ. J. Agric. Sci., Ain Shams Univ., Cairo, 13(3), 717-729, 2005

\title{
ISOLATION, PURIFICATION AND IDENTIFICATION OF SOME MICROORGANISMS PRODUCE PLANT GROWTH PROMOTING SUBSTANCES (METHYLOTROPHIC BACTERIA)
}

[47]

\author{
Orf, O.M. Heba' ${ }^{1}$; Wedad, E.E. Eweda²; Sawsan, F. Shehata² \\ and H.H. Abo-Taleb ${ }^{1}$
}

\begin{abstract}
Recently, the potential economical importance of the methylotrophic bacteria encouraged the isolation of this group. In the present study five Egyptian isolates were obtained from green leaves surface of legume plants named PPFM.C (ChickPea), PPFM.Ph (Common bean), PPFM.F (Faba bean), PPFM.P (Peanut) and PPFM.S (Soybean), to study their general characters which belonging to methylotrophic bacteria. Morphological studies indicate that all isolates were short rods, gram negative and motile. All Physiological studies to the isolates gave the same results except PPFM.F which could not grow in peptone medium. All isolates were sensitive to Kanamycin but they were resistant to Erythromycin. There was a great range in the ability of the isolates to grow on different sodium chloride concentrations indicating that PPFM.Ph grew well in $5 \%$ sodium chloride, and they were able to excrete and produce cytokinin. Molecular biology studies indicated that there was a great similarity between PPFM.C and PPFM.Ph (99.34\%). Identification was carried out to the5 isolates, PPFM.F may be related to Methylobacterium mesophilicum, PPFM.P may be related to M. fujisawaense and PPFM.Ph, PPFM.C and PPFM.S were related to $M$. radiotolerans.
\end{abstract}

Key words: Methylotrophs, Pink-Pigmented Facultatively Methylotrophic (PPFM), Green leaves of legume plants, Cytokinin, Methylobacterium sp.

\section{INTRODUCTION}

The last century, the vast development of industrial chemistry created different agrochemical compounds for use as fertilizers, pesticides, soil conditioners and phytohormons. The extensive use of such chemicals for increasing production of sustainable agriculture led to increase both production cost and environmental pollution. However one of the most important factors to build up soil fertility

1- Department of Agricultural Microbiology, Soils, Water \& Environment Research Institute, Agricultural Research Center, Giza, Egypt.

2- Department of Agricultural Microbiology, Faculty of Agriculture, Ain Shams University, Shoubra El-Kheima, Cairo, Egypt. 
Arab Univ. J. Agric. Sci., Ain Shams Univ., Cairo, 13(3), 717-729, 2005

and plant growth is the ability of microorganisms to produce and release various growth promoting substances. Plant Growth Promoting Rhizobacteria (PGPR) can affect plant growth in two different ways indirectly or directly. The indirect promotion of plant growth occurs when PGPR lessen or prevent the deteriorus effect of one or more phytopathogenic organisms. While, the direct promotion of plant growth by PGPR from the most potential either providing the plant with a component that is synthesized by the bacterium or facilitating the uptake of certain nutrients from the environment (Frankenberger \& Arshad, 1995 and Gilick, 1995).

Many microbes live on phylloplane and feed on materials leached from the leaf. A variety of organic and inorganic substances has been found in leaf leachates including all essential elements, free sugars and alcohols, all amino acids, many organic acids, growth regulating substances, vitamins, alkaloids, phenols, auxins and cytokinins (Basile et al 1985;

\section{Leifert et al 1991 and Holland \& Polacco, 1994).}

The term methylotrophic is used to describe a wide variety of bacteria which can utilize single carbon compounds more reduced than carbon dioxide as a sole carbon source. Bacteria which utilize only such compounds are termed obligate methylotrophs; while those which can utilize more complex organic molecules are termed facultatively methylotrophes (Whittenbury and Dalton, 1981)

The most abundant group of methylotrophs isolated from surfaces of green plants were the Pink Pigmented Facultatively Methylotrophs (PPFMs) (Corpe \& Basile, 1982; Corpe, 1985 and Hoon \& Kim, 1989).

In addition to their ability to colonize the phyllosphere, members of Methylobacterium were also able to colonize the rhizosphere of the tested plant species (Omer, 2004).

The present work is aimed to isolate, purify and identificate some microorganisms produce plant growth promoting substances (PPFMs) from leaf surfaces of some legume plants.

\section{MATERIAL AND METHODS}

\section{Isolation of Pure Colonies}

Ammonium Mineral salts medium (AMS) was used to isolate and enrichment PPFMs bacteria, which content $\left(\mathrm{gL}^{-1}\right)$ : $\mathrm{MgSO}_{4} \cdot 7 \mathrm{H}_{2} \mathrm{O} 1.0 ; \mathrm{CaCl}_{2}$ 0.2 ; iron complex 0.004 ; (NH4) ${ }_{2} \mathrm{SO}_{4} 0.5$; Trace elements solution $0.5 \%(\mathrm{vol} / \mathrm{vol})$; agar 12.5 (if added) and supplemented with methanol $0.05 \%$ (vol/vol) (MetAMS medium) (Whittenbury et al 1970). Green leaves obtained from different legume plants were collected from different locations (Behera, Giza and Nubaria Research stations, Agricultural Research Center (ARC) and

1- Department of Agricultural Microbiology, Soils, Water \& Environment Research Institute, Agricultural Research Center, Giza, Egypt.

2- Department of Agricultural Microbiology, Faculty of Agriculture, Ain Shams University, Shoubra El-Kheima, Cairo, Egypt. 
used to obtain single colony with Pink Pigmented Facultative Methylotrophs (PPFMs) according to Corpe, (1985). Identification was carried out according to Bergey's manual of determinative bacteriology, $9^{\text {th }}$ edition, (1994).

\section{Morphological and Staining Characteristics (Barrow and Feltham, 1993)}

Pure colonies were examined microscopically to determine gram reaction and shape. Whereas motility was tested in liquid culture. Morphology of colonies were determined for each isolate which streaked on solid Met-AMS medium and incubated for 3 days at $28^{\circ} \mathrm{C}$, and using a binocular microscope.

\section{Physiological Characteristics of PPFM isolates (Jenkins and Jones, 1987)}

\section{III.1. Catalase test}

Isolates growth for $24 \mathrm{~h}$ were emulsified with 20 vol. $\mathrm{H} 2 \mathrm{O} 2$ and observed for the production of effervescence for up to $1 \mathrm{~min}$.

\section{III.2. Carbon source utilization}

Different carbon sources D- glucose (D- $\left.\mathrm{C}_{6} \mathrm{H}_{12} \mathrm{O}_{6}\right)$ and ethanol $\left(\mathrm{CH}_{3} \mathrm{CH}_{2} \mathrm{OH}\right)$ were used separately to study the ability of PPFM isolates to grow on different carbon sources by adding $0.2 \%(\mathrm{w} / \mathrm{vol})$ on carbon base in AMS agar medium.

\section{III.3. Citrate utilization}

Plates containing Simmon's citrate agar medium (Simmon, 1926) were inoculated with $1 \mathrm{ml}$ of each obtained PPFM isolates and incubated for $96 \mathrm{~h}$ at $28^{\circ} \mathrm{C}$ then examined for citrate utilization.

\section{III.4. Growth on peptone rich nutrient agar (Oxoid CM55), (Green et al 1988)}

Peptone rich nutrient agar plates were prepeared and streaked with loopful of each PPFM isolates which obtained and incubated at $28^{\circ} \mathrm{C}$ for $96 \mathrm{~h}$ then examined for growth.

\section{III.5. Starch hydrolysis (Lelliot and Stead, 1987)}

Starch was added at $0.2 \%(\mathrm{w} / \mathrm{vol})$ before sterilization of Met-AMS. agar medium $\left(121^{\circ} \mathrm{C}\right.$ for $\left.20 \mathrm{~min}\right)$, plates were inoculated with $1 \mathrm{ml}$ of each PPFM isolate and incubated for $96 \mathrm{~h}$ at $28^{\circ} \mathrm{C}$ .Iodine solution was used to flood the incubated plates then examined for starch hydrolysis.

\section{III.6. Acid production from glucose (Jenkins and Jones, 1987)}

Met-AMS broth medium with $1 \%(\mathrm{w} / \mathrm{vol})$ glucose was inoculated by each isolate and incubated at $28^{\circ} \mathrm{C}$ from 1 to 7 days, Using an equal volume of 0.2 $\%(\mathrm{w} / \mathrm{v})$ aqueous bromothymol blue

\section{III.7. Staining of metachromatic granules (volutin granules) by using methylene blue (Mahmoud, 1988)}

Prepared A good smear of each PPFM isolate and flood its slides with 1\% methylene blue solution for $1 \mathrm{~min}$, after removing methylene blue solution adding 
4

Orf; Eweda; Shehata and Abo-Taleb

a drop of oil immersion and examined these slides for volutin granules.

III.8. Acetylene Reduction Activity (ARA)

The ARA of PPFM cultures were estimated according to Hardy et al
(1973) using DEL-SI-DN 200/250 gas chromatograph.

\section{III.9. Antibiotic resistance of PPFM isolates (Quinn et al 1994)}

Five antibiotics were used as shown in Table (1) to estimate the antibiotic resistance of obtained PPFM isolates. 
Arab Univ. J. Agric. Sci., Ain Shams Univ., Cairo, 13(3), 717-729, 2005

Table 1. Antibiotics resistance standard range (Inhibition zone diameter, $\mathrm{mm}$ )

\begin{tabular}{|lcccc|}
\hline \multicolumn{1}{|c}{ Antibiotics } & Concentration & \multicolumn{3}{c|}{ Diameter (mm) } \\
& $\mathrm{s}$ & Resistant & Intermediate & Susceptible \\
\hline Ampcillin & $10 \mu \mathrm{g}$ & $\leq 13$ & $14-16$ & $\geq 17$ \\
Bacitracin & $10 \mathrm{unit}$ & $\leq 8$ & $9-12$ & $\geq 13$ \\
Erythromycin & $15 \mu \mathrm{g}$ & $\leq 15$ & $16-20$ & $\geq 21$ \\
Kanamycin & $30 \mu \mathrm{g}$ & $\leq 13$ & $14-17$ & $\geq 18$ \\
Streptomycin & $50 \mu \mathrm{g}$ & $\leq 11$ & $12-14$ & $\geq 15$ \\
\hline
\end{tabular}

\section{III.10. Tolerance to salinity}

Gradient salt concentrations of 0.5 , $1.0,2.0,3.0,4.0,5.0$ and $6.0 \% \mathrm{NaCl}$ were prepared in Met-AMS broth to evaluate the tolerance of obtained PPFMs isolates to salinity, different concentrations of $\mathrm{NaCl}$ were inoculated by $1 \mathrm{ml}$ of new PPFM cultures and incubated at $28^{\circ} \mathrm{C}$ for $0,24,48,96$ and 144 hours and counting the appearance colonies on Petri dishes contain Met-AMS Agar medium at the same time in the same order.

\section{Cytokinin production}

Radish (Raphanus sativus) cotyledons bioassay was used as qualitative method according to Lethman (1968) to study the ability of PPFM isolates to produce and release cytokinin .

\section{Molecular biology studies}

Studying the similarity among the PPFM isolates using protein pattern and random amplification of DNA as follows:

\section{V.1. Electrophoretic studies of PPFMs protein by sodium dodecyl sulphate polyachrelamide gel electrophoresis (SDS-PAGE)}

Protein pattern of PPFM isolates was done according to Laemmili (1970), using standard protein marker at three molecular weights $(66,48$ and 29 K.d) and data were analyzed by $1 . \mathrm{D}$ Advanced program

1- Department of Agricultural Microbiology, Soils, Water \& Environment Research Institute, Agricultural Research Center, Giza, Egypt.

2- Department of Agricultural Microbiology, Faculty of Agriculture, Ain Shams University, Shoubra El-Kheima, Cairo, Egypt. 
Arab Univ. J. Agric. Sci., Ain Shams Univ., Cairo, 13(3), 717-729, 2005

\section{V.2. Random Amplified Polymorphism DNA (RAPD) analysis}

RAPD analysis of PPFM isolates was done according to Welliams et al (1990). Protocol was carried out by using three primers: Primer No.1, Primer No.2 and Primer No.5. The different molecular weight of bands were determine against PCR marker promega G317A by un weighted pair-group method based on arithmetic mean (UPGMA).

\section{RESULTS AND DISCUSSION}

Five isolates of methylotrophs were obtained from green leaves of legume plants, the isolates and their sources were listed in Table (2), Corpe and Basile (1982) reported that the most abundant group of methylotrophs isolated from surfaces of green plants were the pinkpigmented facultatively methylotrophs (PPFMs).

Table 2. Code of PPFM isolates obtained from leaf surfaces of different legume plants

\begin{tabular}{|llll|}
\hline $\begin{array}{c}\text { Location } \\
\text { sites }\end{array}$ & $\begin{array}{c}\text { Plant leaf } \\
\text { samples }\end{array}$ & Scientific name & $\begin{array}{c}\text { Code of } \\
\text { isolates }\end{array}$ \\
\hline Behera & Chickpea & Cicer arietinum & PPFM. C \\
Giza & $\begin{array}{l}\text { Common } \\
\text { bean }\end{array}$ & $\begin{array}{l}\text { Phaseolus } \\
\text { vulgaris }\end{array}$ & PPFM.Ph \\
Nubaria & Faba bean & Viciafaba & PPFM.F \\
Nubaria & Peanut & Arachis & PPFM.P \\
\hline
\end{tabular}

Data presented in Table (3) and Fig. (1) show that PPFM isolates nearly have the same morphological and cultural characteristics. Microscopically examination indicates that, all isolates were short rods, gram negative and motile. Morphology of colonies was done using binocular indicating that all isolates have the same cultural properties except PPFM.F colonies which appear bigger than the others.

Data in Table (4) reveal some physiological characteristics of PPFM isolates obtained from green leaves of different legume plants. The five isolates were catalase positive, utilize D-glucose, ethanol and citrate. All isolates grew well on peptone rich nutrient agar except PPFM.F. They were not able to hydrolyze starch, did not produce acid from glucose, contained volutine granules, while Acetylene Reduction Activity ( $\mu$ mole $\mathrm{C}_{2} \mathrm{H}_{4} / \mathrm{h}$ ) was negative that mean the five isolates could not fix nitrogen. These results are in agreement with those obtained by Corpe \& Basile (1982); Jinkens \& Jones (1987) and Hoon \& Kim (1989).

\section{Resistance of PPFM isolates to antibiotics}

For studying antibiotic resistance of PPFM isolates using Table (1) to clear the data in Table (5) which show that, PPFM.Ph was the most susceptible one

1- Department of Agricultural Microbiology, Soils, Water \& Environment Research Institute, Agricultural Research Center, Giza, Egypt.

2- Department of Agricultural Microbiology, Faculty of Agriculture, Ain Shams University, Shoubra El-Kheima, Cairo, Egypt. 


\section{Identification of methylotrophic bacteria}

for various antibiotics, PPFM.P had the highest resistance among all tested isolates. Kanamycin had the highest inhibiting effect on bacterial growth if compared with Erythromycin among other antibiotics. These data were in agreement with Green et al (1988).

Effect of different salt concentrations on PPFM isolates

Data in Table (6) indicate that four isolates can not grow in $5 \% \mathrm{NaCl}$, but PPFM.Ph isolate can grow at the same concentration, while there is no growth at $6 \% \mathrm{NaCl}$ concentration for all PPFM isolates . In case of PPFM.S isolate there is no growth in $4 \% \mathrm{NaCl}$ concentration (after 144h).

\section{Cytokinin production}

Figure (2) illustrate that PPFM isolates have The ability to produce and release cytokinin as measured by radish cotyledons bioassay, PPFM.Ph isolate gave the highest amount of releasing 
Arab Univ. J. Agric. Sci., Ain Shams Univ., Cairo, 13(3), 717-729, 2005

Table 3. Some morphological and cultural characteristics of PPFM isolates:

\begin{tabular}{|c|c|c|c|c|c|}
\hline $\begin{array}{c}\text { Isolates } \\
\text { Characters }\end{array}$ & PPFM.C & PPFM.Ph & PPFM.F & PPFM.P & PPFM.S \\
\hline $\begin{array}{l}\text { Morphological } \\
\text { characters(Smear) }\end{array}$ & & & & & \\
\hline Cell shape & Short rod & Short rod & Short rod & Short rod & Short rod \\
\hline Gram reaction & $\mathrm{G}^{-\mathrm{ve}}$ & $\mathrm{G}^{\text {-ve }}$ & $\mathrm{G}^{\text {-ve }}$ & $\mathrm{G}^{-\mathrm{ve}}$ & $\mathrm{G}^{\text {-ve }}$ \\
\hline Motility & Motile & Motile & Motile & Motile & Motile \\
\hline $\begin{array}{l}\text { Colony morphology } \\
\text { (solid medium) }\end{array}$ & & & & & \\
\hline Shape & Circular & Circular & Circular & Circular & Circular \\
\hline Diameter $(\mathrm{mm})$ & $1.0-2.0$ & $0.5-1.0$ & $2.0-3.0$ & $0.5-1.0$ & $1.0-2.0$ \\
\hline Opacity & Opaque & Opaque & Opaque & Opaque & Opaque \\
\hline Elevation & Convex & Convex & Convex & Convex & Convex \\
\hline Edge & Entire & Entire & Entire & Entire & Entire \\
\hline Color & Pink & Pink & Pink & Pink & Pink \\
\hline
\end{tabular}

1- Department of Agricultural Microbiology, Soils, Water \& Environment Research Institute, Agricultural Research Center, Giza, Egypt.

2- Department of Agricultural Microbiology, Faculty of Agriculture, Ain Shams University, Shoubra El-Kheima, Cairo, Egypt. 
Fig. (1): General morphological characteristics of PPFM isolates.
(A) Gram staining.
(B) Growth on Met-AMS agar plates.
(C) Colonies appearance on Met-AMS agar medium.

Table 4. Some physiological characteristics of PPFM isolates obtained from green leaves of different legume plants

\begin{tabular}{|c|c|c|c|c|c|}
\hline Isolate & PPFM.C & PPFM.Ph & PPFM.F & PPFM.P & PPFM.S \\
\hline Catalase & + & + & + & + & + \\
\hline $\begin{array}{l}\text { Carbon source utilization } \\
\text { D-Glucose }\end{array}$ & + & + & + & + & + \\
\hline Ethanol & + & + & + & + & + \\
\hline Citrate & + & + & + & + & + \\
\hline $\begin{array}{l}\text { Growth on peptone rich } \\
\text { nutrient agar (Oxiod CM } \\
\text { 55) }\end{array}$ & + & + & - & + & + \\
\hline Starch hydrolysis & - & - & - & - & - \\
\hline $\begin{array}{l}\text { Acid production from } \\
\text { glucose }\end{array}$ & - & - & - & - & - \\
\hline Volutine granules & + & + & + & + & + \\
\hline $\begin{array}{l}\text { Acetylene reduction } \\
\text { activity (ARA) }\end{array}$ & - & - & - & - & - \\
\hline
\end{tabular}

Table 5. Effect of different antibiotics on PPFM isolates growth as measured by diameter of Inhibition zone ( $\mathrm{mm}$ )

Zone Diameter mean (mm)

PPFM.S PPFM.P PPFM.F PPFM.Ph PPFM.C Concentration Antibiotics

$\begin{array}{lllllll}15.0 & 8.3 & 10.6 & 9.6 & 13.0 & 10 \mu \mathrm{g} & \text { Ampcillin }\end{array}$

Arab Univ. J. Agric. Sci., 13(3), 2005 
Orf; Eweda; Shehata and Abo-Taleb

\begin{tabular}{|rrrrrrl|}
12.0 & 8.3 & 07.6 & 9.6 & 12.0 & $10 \mathrm{u}$ & Bacitracin \\
11.0 & 8.3 & 10.6 & 12.0 & 11.0 & $15 \mu \mathrm{g}$ & Erythromycin \\
18.0 & 17.0 & 18.0 & 20.0 & 16.0 & $30 \mu \mathrm{g}$ & Kanamycin \\
09.0 & 15.3 & 12.6 & 19.3 & 15.0 & $50 \mu \mathrm{g}$ & Streptomycin \\
\hline
\end{tabular}

Table 6. Effect of different $\mathrm{NaCl}$ concentrations on the growth of PPFM isolates on Met-AMS agar medium (after 144h).

\begin{tabular}{|lccccccccc|}
\hline $\begin{array}{c}\mathrm{NaCl} \\
\text { concent. }\end{array}$ & 0.0 & 0.5 & 1.0 & 2.0 & 3.0 & 4.0 & 5.0 & 6.0 \\
Isolates & & & & & & & & \\
& & & & & & & & \\
\hline PPFM.C & +++ & +++ & ++ & ++ & ++ & + & - & - \\
PPFM.Ph & +++ & +++ & +++ & +++ & +++ & ++ & + & - \\
PPFM.F & +++ & +++ & +++ & +++ & ++ & + & - & - \\
PPFM.P & +++ & +++ & +++ & ++ & ++ & + & - & - \\
PPFM.S & +++ & +++ & ++ & + & + & - & - & - \\
\hline
\end{tabular}
$(+++)>10^{6}-10^{7} \mathrm{cfu}$
$(++) \geq 10^{4}-10^{5} \mathrm{cfu}$
$(+)<10{ }^{4} \mathrm{cfu}$
(-) no growth

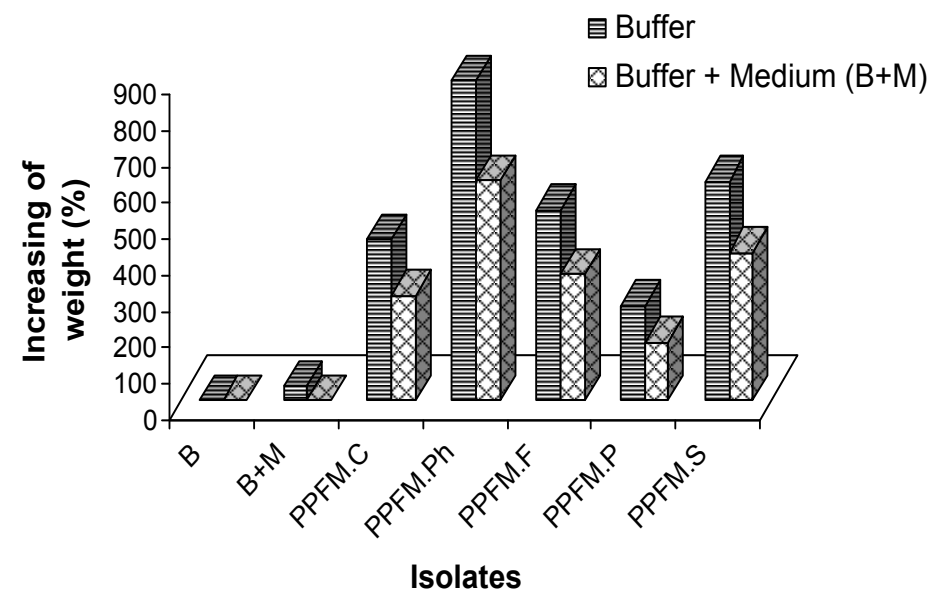

Arab Univ. J. Agric. Sci., 13(3), 2005 
11

Identification of methylotrophic bacteria

Fig. 2. Increases percentage of radish cotyledons weight as affected by cytokinin release from different PPFM isolates

Arab Univ. J. Agric. Sci., 13(3), 2005 
Arab Univ. J. Agric. Sci., Ain Shams Univ., Cairo, 13(3), 717-729, 2005

cytokinin as compared to other different tested PPFM isolates. Generally, all obtained PPFM isolates had positive effect on producing and releasing cytokinin by following order: PPFM.Ph $>$ PPFM.S $>$ PPFM.F $>$ PPFM.C $>$ PPFM.P. This result was in agreement with Holland (1997) who reported that, cytokinins are produced by the microbial symbionts of plants not by plants them selves. Also Omar (2004) reported that several Methylobacterium spp produce cytokinins, e.g. zeatin riboside.

\section{Molecular biology studies}

To study the similarity among PPFM isolates, protein pattern and Random Amplification of the DNA were carried out. It is clear from Fig. (3), that the similarity of protein profiles for the five PPFM isolates ranged from 34.22 to 65.99 where PPFM.F came in a separated group within 34.22 similarities with the other four isolates. Among the bacterial PPFM isolates the highest similarity (65.99) was between PPFM.Ph and PPFM.C, while the similarity between PPFM.S and the group containing PPFM.Ph and PPFM.C was 58.32. The lowest similarity (34.22) was between PPFM.F and any of the other isolates.

Data in Fig. (4) show the Random Amplification of the DNA from the five PPFM isolates, there were different degrees of polymorphism according to the used primers. There was high similarity between PPFM.C and PPFM.Ph (99.34) when primer No.1 was used.

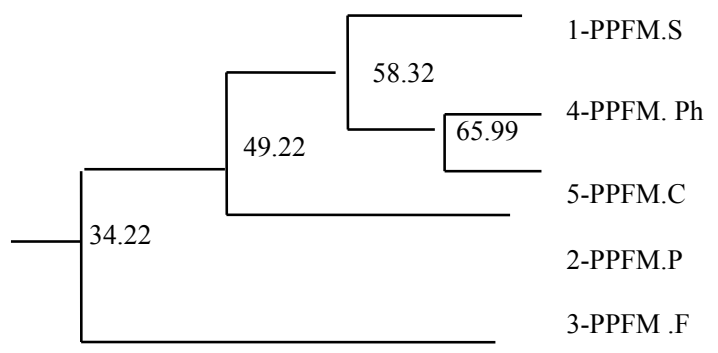

1- Department of Agricultural Microbiology, Soils, Water \& Environment Research Institute, Agricultural Research Center, Giza, Egypt.

2- Department of Agricultural Microbiology, Faculty of Agriculture, Ain Shams University, Shoubra El-Kheima, Cairo, Egypt. 
Arab Univ. J. Agric. Sci., Ain Shams Univ., Cairo, 13(3), 717-729, 2005

Fig. 3. Protein pattern of PPFM isolates using Sodium Dodecyle Sulphate Poly Acrylamide Gel Electrophoresis (SDS-PAGE)

1- Department of Agricultural Microbiology, Soils, Water \& Environment Research Institute, Agricultural Research Center, Giza, Egypt.

2- Department of Agricultural Microbiology, Faculty of Agriculture, Ain Shams University, Shoubra El-Kheima, Cairo, Egypt. 
Arab Univ. J. Agric. Sci., Ain Shams Univ., Cairo, 13(3), 717-729, 2005

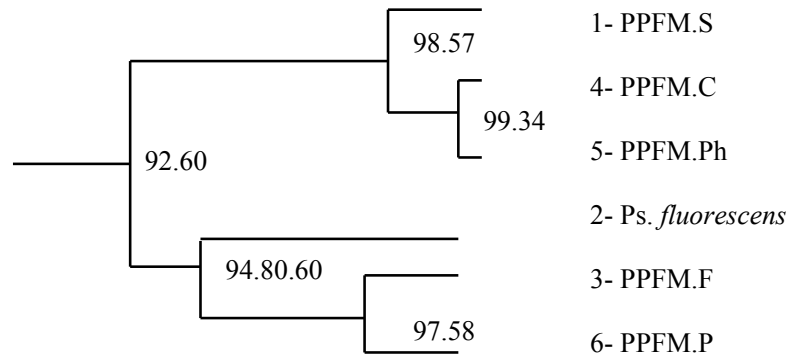

Fig. 4. Random Amplified Polymorphism DNA (RAPD) analysis

Primer No.2 showed the highest polymorphism as the bacterial isolates fell in two main groups with 66.28 similarity between them. Among the PPFM isolates and when primer No. 2 used, the highest similarity (88.04) was between PPFM.C and PPFM.Ph while the lowest similarity (66.28) was between PPFM.Ph or PPFM.C and any of the other isolates .On the other hand, when primer No.1 and No. 5 were used, high similarity was observed with ranges from 92.60 to 98.57 for primer No.1and 99.18 for primer No.5. In general, the low similarity in protein profiles among the used bacterial isolates could be attributed to difference in metabolism or secretion of some different metabolites .The high similarity among the bacterial isolates is an indication to the highly genetically relateness among them. This high similarity could be considered when classifying these isolates. There have been some comparative of methylotrophic bacteria according to Urakami et al (1985) and Holland (1997).

In conclusion, according to Bergey's Manual of Determinative Bacteriology, $9^{\text {th }}$ Edition (1994) all PPFM bacterial

1- Department of Agricultural Microbiology, Soils, Water \& Environment Research Institute, Agricultural Research Center, Giza, Egypt.

2- Department of Agricultural Microbiology, Faculty of Agriculture, Ain Shams University, Shoubra El-Kheima, Cairo, Egypt. 
Arab Univ. J. Agric. Sci., Ain Shams Univ., Cairo, 13(3), 717-729, 2005

isolates tested and identified in the present study may be related to one genus Methylobacterium but belong to different species where PPFM.F may be related to Methylobacterium mesophilicum, PPFM.P may be related to Methylobacterium fujisawaense and PPFM.Ph, PPFM.C and PPFM.S may be related to Methylobacterium radiotolerans.

\section{REFERENCES}

Barrow, G.I. and R.K.A. Feltham (1993). Cowan and Steel's Manual for the Identification of Medical Bacteria. $3^{\text {rd }}$ Ed., 330 p. Cambridge, University Press, London.

Basile, D.V.; M.R. Basil and W.A. Corpe (1985). Vitamin B12 stimulated growth and development of Jungermmannata leiantha (Groll) and Gvmnocdea inflata (Huds). Dum. (Hepatieae). Bryologtst, 88 (2):77-81.

Bergey's Manual of Determinative Bacteriology $9^{\text {th }}$ Ed (1994). Edited by Williams and Wilkins. Baltimore, Maryland, United States of America, $\boldsymbol{p p}$. $88-90 \& 145$.

Corpe, W.A. (1985). A method for detecting methylotrophic bacteria on solid

surfaces.J.Microbiol.Methods,3:215-221. Corpe, W.A. and D.V. Basile (1982). Methanol utilizing bacteria associated with green plants. Dev. Indust. Microbiol. 23: 483-493.
Frankenberger, Jr. W.T and M. Arshad (1995). Phytohormons in Soils; Microbial Production and Function, pp. 1-10, Marcel Dekker, Inc.,New York.

Gilick, B.R. (1995). The enhancement of plant growth by free living bacteria. Can . J. Microbiol. 41:109-117.

Green, P.N.; I.J. Bousfield and D. Hood (1988). Three new Methylobacterium species:M.rhodesianum sp. nov., M.zatmanii sp.nov., and M. fujisawaense sp.nov. Intern. J. Syst. Bacteriol., 38 (1):124-127.

Hardy, R.W.F.; R.C. Burns and R.D. Holstel (1973). Application of the acetylene-ethylene assay for measurements of nitrogen fixation. Soil. Biol. Biochem. 5: 47-81.

Holland, M.A. (1997). Methylobacterium and plants, Recent Res. Devel. in Plant Physiol. I: 207-213.

Holland, M.A. and J.C. Polacco (1994). PPFMs and other covert contaminant: is there more to plant physiology than just plant?. Ann. Rev. Plant Physiol. Plant Mol. Bio. 45: 197-209.

Hoon, Y.S. and Y.M. Kim (1989). Isolation and characterization of pink pigmented facultative methylotrophic bacteria. Kor. J. Microbiol. 27 (1): 63-69. Jenkins, $O$. and D. Jones (1987). Taxonomic studies on some gram negative methylotrophic bacteria. J. Gen. Microbiol., 133:453-473.

Laemmili, U.K. (1970). Clavage of structural proteins during assembly of the

1- Department of Agricultural Microbiology, Soils, Water \& Environment Research Institute, Agricultural Research Center, Giza, Egypt.

2- Department of Agricultural Microbiology, Faculty of Agriculture, Ain Shams University, Shoubra El-Kheima, Cairo, Egypt. 
16

Orf; Eweda; Shehata and Abo-Taleb

head of bacteriophage T4. Nature 227: primers are useful as genetic markers. 680-685.

Leifert, C.; J.Y. Richie and W.M.

Waites (1991). Contaminants of plant tissue and cell cultures. World $\boldsymbol{J}$. Microbiol. Biotechnol., 7: 452-469.

Lelliot, R.A. and D.E. Stead (1987). Methods for the diagnosis of bacterial diseases of plants. Methods in Plant Pathology Vol. 2, Ed. pp. 216 Preece. T.F., BlackWell Scientific Puplication, New York.

Lethman D.S. (1968). A new cytokinin bioassay and naturally occurring cytokinin complex. Wightman, $\mathrm{F}$ and G.Setterfield (eds). Biochemistry and Physiology of Plant Growth Substances. pp. 19-35, Runge Press, Ottawa.

Mahmoud, S.Z. (1988). Applied Practical Microbiology (in Arabic), pp. 60-83, Anglo Egyptian Bookshop, Cairo.

Omer, Z.S. (2004). Bacterial Plant Associations with Special Focus on Pink Pigmented Facultative Methylotrophic Bacteria (PPFMs), pp. 25-30. Ph.D. Thesis. Plant Pathology Dept.Biocontrol unit. Agriculture Fac., Suecia Univ., Agraria.

Quinn, P.J.; M.E. Carter; B.K. Markey and J.R. Carter (1994). Clinical Vet. Microbiology, pp. 220-242, Wolf., Publishing Tavis Tock, London.

Simmon, J.S. (1926). Agriculture medium for differentiating organisms of typhoid groups and for the isolation of certain fungi. J. Infect. Dis. 39: 209-211. Urakami, T.; J. Tamaoka and K. Komagata (1985) DNA base composition and DNA-DNA homologies of methanol utilizing bacteria. J. Gen. Applied. Microbiol. 31:243-253.

Welliams, J.C.K.; A.R. Kupelik; J.A. Rafalski and S.V. Tingey (1990). DNA polymorphism amplified by arbitrary 
Identification of methylotrophic bacteria

Nucleic Acid Res. 18: 6531-6535.

Whittenbury, R.; H. Dalton (1981). The methylotrophic bacteria. In: The Prokaryotes - a Handbook on Habitats. Isolation and Identification of Bacteria.Vol.1, pp. 894-902, (Starr, M.P.; H. Stolop; H.G. Truper; A. Balows and H.G. Schlegel, Editors), Berlin.

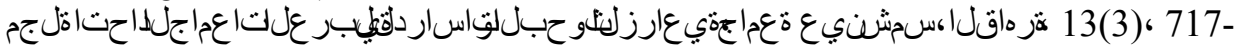
729، 2005

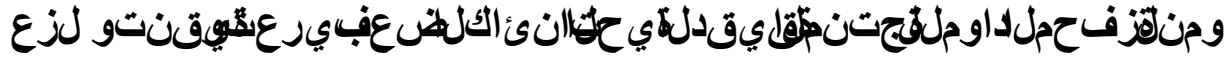

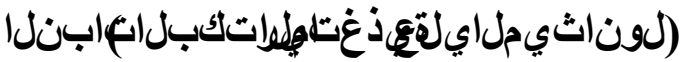

]47[
Whittenbury, R.; K. C. Philips and J.F. Wilkinson (1970). Enrichment, isolation and some properties of methane utilizing bacteria. J. General Microbiol. 61: 205218.

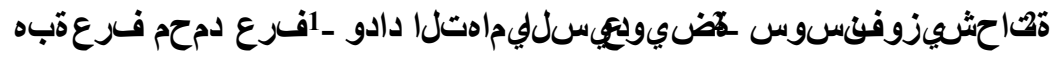

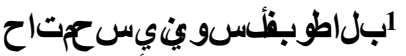

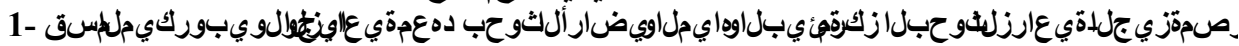

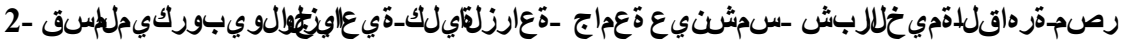

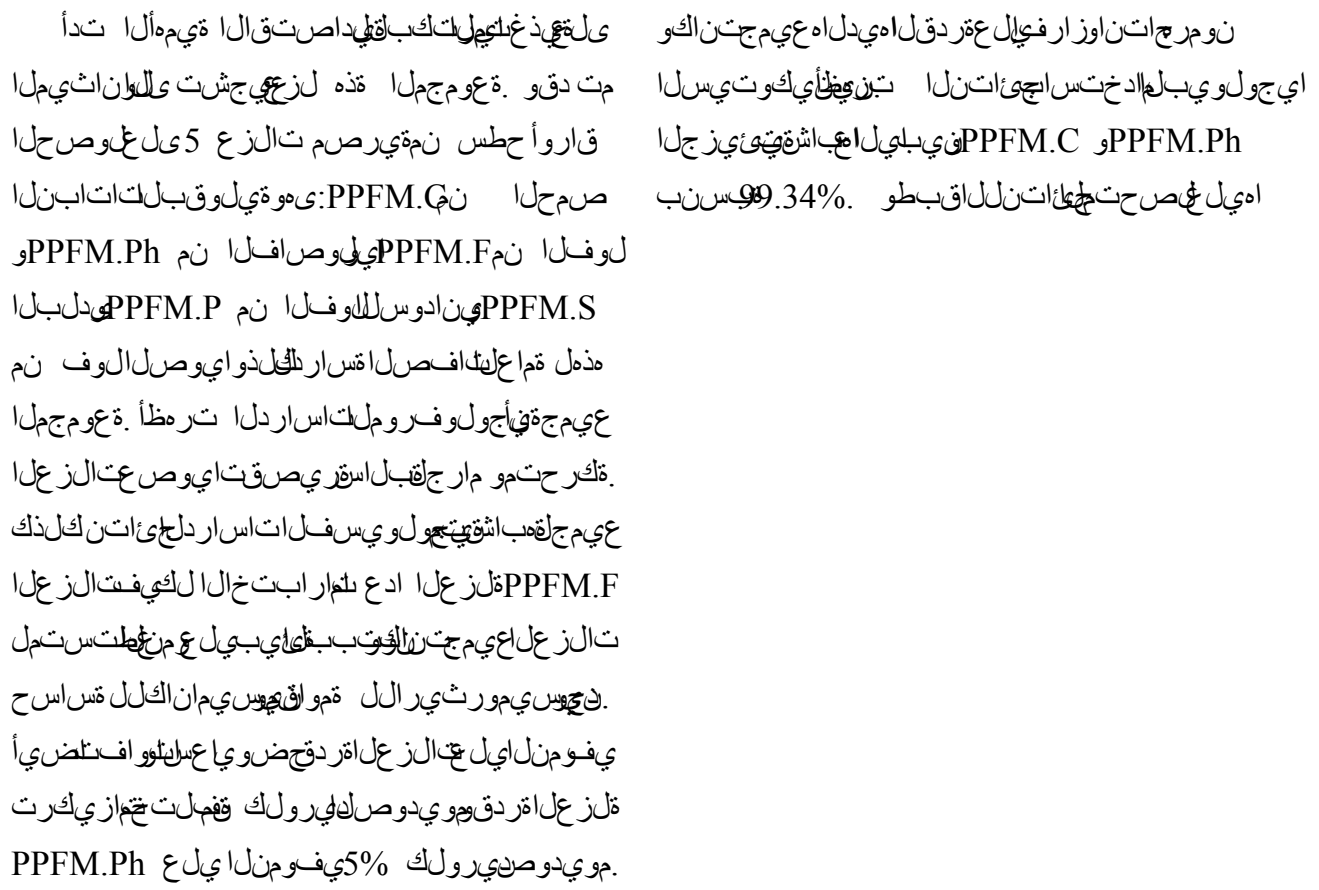


Arab Univ. J. Agric. Sci., Ain Shams Univ., Cairo, 13(3), 717-729, 2005

PPPFM.Ph وPPFM.C و و PPFM.S

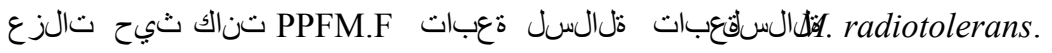

Methylobacterium mesophilicum

وPPFM.P السل ة:وباتM. fujisawaense.

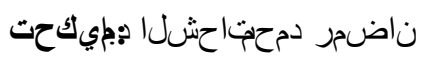

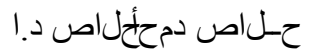

1- Department of Agricultural Microbiology, Soils, Water \& Environment Research Institute, Agricultural Research Center, Giza, Egypt.

2- Department of Agricultural Microbiology, Faculty of Agriculture, Ain Shams University, Shoubra El-Kheima, Cairo, Egypt. 